\title{
Education Informatization and University Teaching Reform
}

\author{
Shujuan $\mathrm{Wu}^{1, \mathrm{a}}$, Tan $\mathrm{Na}^{2, \mathrm{~b}}$ \\ ${ }^{1}$ Research Institute for University Development, Yangtze University, Jingzhou, 434023, China \\ ${ }^{2}$ Research Institute for University Development, Yangtze University, Jingzhou, 434023, China \\ aemail: jks@yangtzeu.edu.cn, bemail:nanahn@163.com
}

Keywords: Education informatization, University teaching, Reformation

\begin{abstract}
Network informatization age has brought great effect to higher Education. How to use the positive benefits and overcome the negative effects brought by the informatization and how to improve the teaching quality become important topics in today's education research. This paper focuses on analyzing the characteristics of education informatization and problems existing in university teaching and managing, aiming to explore university teaching reform measures from the teaching concept, teaching content, teaching method, learning method and management way.
\end{abstract}

\section{Definition and characteristics of education informatization}

\section{A. Definition of education informatization}

Educational information refers to make use of modern information technology such as computers, multimedia and network technology in the field of education to promote updating of educational concepts, the reform of education content and methods and learning ways, to train high-quality innovative talents and upgrade educational quality, to establish new educational system which meets the needs of social development.

\section{B. The main characteristics of education informatization}

There are several features when talking about education informatization. Here two points will be illustrated as follows:

From the point of technology, the transmission equipments are digitalized and intelligent. The routes of dissemination are also networked and multi-mediazatized. Besides the propagation models are open and interactive.

From the point of education, there appear diverse and global education resources. Education process becomes interactive and personalized. Furthermore, education environment is combined with the virtual one with teaching information being displayed on multimedia. Then, collaborative and autonomous learning styles are advocated and education management is concealed and automatic.

\section{Challenges that education informatizaion brings to university teaching}

\section{A. Teaching}

1) Teaching concept: from authority to humanity: Education informatization while has caused profound changes of university teaching ideas. The "three centers" of traditional university has gradually changes into another model of people-oriented and student-centered, innovative ability training instead of just passing knowledge and learning various educational and cultural resources based on textbooks.

2) Teacher's role: from the subject to guide: With the coming of education informatization, students can understand the information about relevant professional or curriculum information in a short time with the help of network transmission and the multimedia, opening and interactive communication mode. Teachers only need to give some guidance to some certain extent, changing from being professional authority to being student's guide.

3) Teaching methods: from the "one-way" to "interaction": Educational information offers the teacher a chance to make better use of a variety of dissemination channels such as classroom 
teaching, network resources, and chatting software to communicate with students that teachers and students can study and communicate together, achieving effective interactions.

\section{B. Learning}

1) Study style: from simplification to diversification: With internet, students can collect the information and knowledge whichever they are interested in and want to know in the shortest possible time. Through cooperative communication and collaborative study, students are able to learn new knowledge and enhance capacity. Futurists Negroponte pointed out that 10 years later, the youth will have much more selections because not only nerd who read just the books can achieve profound knowledge, young people with a variety of different cognitive styles, learning methods and performance behaviors, can also succeed in the end.[1]

2) Learning content: from books to network: The diversification of education resources and the openness of the route of transmission provide a platform for the students to do extensive learning. Each student can have access to different disciplines to understand and collect all kinds of information through computer and network. What's more, they can communicate with teachers or scholars on an issue via effective use of network. The time when learning is only limited to a book or a textbook has disappeared forever.

3) Learning attitude: from "passive" to "active": In traditional teaching mode, students study very passively, all the learning obeying teacher's arrangement. But in education informatization environment, students can make full use of electronic media, computer network technology which may stimulate their learning interest and motivation and arouse their thirst for knowledge, then obtain knowledge with a fundamental change attitude from "want me to learn" to "I want to learn".

4) Evaluation mode: from simplification to diversification: Traditional university management mode and the administrative system have also had revolutionary change due to the construction and development of the campus network, realizing the modernization of management methods [2]. In education informatization age, the exam content changes. Students are accessed not only from book knowledge but also according to students' comprehensive quality, creative and innovative ability together with personality development.

\section{Problem of university teaching in education informatization age}

\section{A. Problems existing in the university teaching philosophy}

1) Teaching concept is relatively backward: The application of multimedia and computer network technology in education provides communicating channels and convenient means to university teaching. Even if some teachers use multimedia, they just transplant textbook knowledge into simple PPT. The relationship between teachers and students is still one-way, they having neglected the openness and interactivity that the education informatization has brought.

2) Teaching goal is not appropriate: Many teachers are used to the habit that be serious in class and relax after class, paying little attention to new information and research dynamic of subjects. Investigation shows that in the issue of training students' critical and creative thinking, students only give 62.9 scores to the teacher, which means that teacher's teaching goals are not correct and students are not satisfied with teachers' teaching.

\section{B. Problems existing in contents of university teaching}

1) The new and old knowledge are not connected well, divorcing from the reality: According to the survey, $28.87 \%$ of students are not very satisfied with teachers' integration of old and new knowledge. $33.49 \%$ of students believe that teachers' ability to combine teaching content with the life and society is just so-so. This shows that there are some problems existing in their knowledge updating and teaching content selection. Teachers do not pay close attention to the latest development of disciplines, nor do they combine the book knowledge with life practice.

2) Teaching and scientific research are detached, while advanced content is insufficient: When teaching, few teachers fused their own scientific research into teaching so that he teaching content and research results are separated. The survey found that $40.99 \%$ of students think that teachers do not combine teaching well with scientific research, and they can not teach the frontier knowledge on discipline in the classroom. 


\section{Problems existing in the university teaching methods}

1) The teaching method is single and lecture-based: Based on two universities' investigation, the author found that the occurring frequency of "teach" behavior on A university is $96.4 \%$, on B university $94.8 \%$. It is said that university teacher's teaching method is still lecture-based, tending to be cramming education, leaving not enough time and room for students to think.

2) Relying too much on multimedia results in communication blank between teachers and students: With the development of information technology, man-machine conversation has instead of teacher-students dialogue appeared in many colleges and universities. The happening frequency of "audio-visual display" in A university happened frequency is $59.6 \%$; in B university is $64.4 \%$. Teacher-student interaction, students discuss and teachers' summary discussion, answer questions in the ratio of teaching process are respectively $0.4 \%, 0 \%, 0.4 \%, 0.4 \%$ in A university, in B university respectively $1.2 \%, 0.4 \%, 0 \%, 0.4 \%$. Questionnaire shows that $16.32 \%$ of students' participation degree is low and $26.53 \%$ of students think the teaching atmosphere is depressing and unattractive.

\section{Problems existing in university students' learning}

1) Depend too much on teacher and lack the spirit of exploration: At present, students in ordinary universities are still take classroom learning as the most basic, book knowledge test being treated as the purpose. When the examination draws near, they need to memorize them, then, they can get good grades.Survey shows that students give 67.52 to teachers in the sheet of providing students learning method guidance and 62.9 in Cultivating students' critical thinking and problem, meaning that university teachers do not give enough give learning method to students who depend too much on teachers.

2) Rely too much on network, learning without thinking: With Internet and information tool, when teacher ask a question in class, students can use mobile to search the answer. When asked in extra-curricular, they can also directly search. Thus, they become dependent on network technology, tending to stay on the surface when deal with a problem rather than think deeply [3].

3) Evaluation system and methods are still single: Some universities continue to used old thinking, old-fashioned way in the field of management, knowing very little about informatization teaching management mode[4].The quality evaluation system of talents is still based on the score, so that there are a lot of students in school studying for high scores, not giving full consideration to students' individual strengths and advantages. Evaluation on teacher is still adopting the uniform assessment standards, pursuing the number of papers and projects, ignoring the teachers' teaching level and quality.

\section{Promoting the Reform Measures of University Teaching}

How to deepen the reform of university teaching, continuously improve the quality of personnel training, are the new characteristics of information age and demands of talent training .

\section{A. Updating teaching ideas}

1) Setting up "student centered" teaching idea: College students are facing a rapidly changing society. Teaching focus no longer on imparting of knowledge and classroom, instead all the teaching activities should be planed with the development of students in mind. Teacher is supposed to be a guide rather than a speaker. Teaching needs to giving full attention to the subjectivity of students, cultivating students' creative thinking and letting students build knowledge system independently and spontaneously.

2) Paying attention to cultivate students' autonomous learning ability: Sheng-tao Ye once said teachers while teaching will make students carry their wits practice frequently and have high ability to understand. In the education informatization age, teachers no longer just pass knowledge, also teach students independent learning ability. Not only do students learn to obtain information, analyze information, and process information, but also learn to ask questions, analyze problems and cultivate problem-solving abilities.

\section{B. Enriching teaching content}

1) Updating teaching content timely, broadening students' horizons: Brubeck once said when the same speech repeated, the novelty will gradually fade away, then, the challenge will be lost [5]. In 
addition to the basic theoretical knowledge from book, teaching content also should enable students to understand the forefront of professional disciplines development results and the latest trends with the help of education information technology. In order to carry out in-depth research, teachers should update their teaching content promptly, refine new scientific research achievements and integrate them into teaching timely, making students understand teachers' questions and study results to enable them to go deeper.

2) Using a variety of channels to increase students' knowledge: In education informatization era, personnel training methods should be diversified. University teaching should not be limited to classroom teaching, but broaden learning channels, using a variety of information platforms for students to understand all kinds of knowledge and information. Through kinds of practical ways, students are able to understand society, then contact with the society and adapt to the society.

Students can take full advantage of college abundant education resources to learn consciously and actively. At the same time, teaching internships, social investigation and production practice, graduation design, industry-university-research cooperation are important channels for students to understand society and contact with the community.

\section{Reform of teaching methods}

1) Using diversified teaching means: Psychological experiments have proved that human get the $83 \%$ of information from visual, $11 \%$ from listening. Therefore, university teachers should continue to reform the traditional single teaching method, teachers can put advanced multimedia technology and computer network technology into the classroom, making the student feel in a virtual environment, to have comprehensive learning knowledge and understand the dynamic development.

2) Expanding teacher-student interaction: Education informatization provides a variety of communication platforms for communication between teachers and students to expand the space for teacher-student interaction. Students can share remote guidance of teachers via two-way video, cultivating their the discovering problem abilities, analyzing problem and solving problems. Make sure that teach students in accordance with their aptitude. The increased interactive sessions help teachers to know more about student's learning and then do effective teaching accordingly.

3) Strengthening the training of teachers' information literacy: Education informatization age put forward new requirements to university teachers' information literacy competency. Deepening the reform of teaching means and methods requires teachers to have strong modern education technology quality and ability, makes them able to combine teaching objectives of this discipline, study subjects, teaching contents, teaching situation etc. with actual situation.

4) Reforming evaluation way, avoiding "one size fits all": The evaluation of university should pay attention to students' personality developmen, students' daily performance is supposed to put into the teaching evaluation. Futherly evaluation should attach great importance to the differences of students to adopt diversified evaluation methods to assess students, taking both assessment of student's common problems and personality problems into consideration.

\section{References}

[1] [U.S.] Negroponte. Being Digiting [M].Haikou, Hainan press.1996:335.

[2]Tsinghua University. Establish the university management system and operational mechanism at the beginning of the twenty-first Century [J]. Tsinghua Journal of Education, 1992(2).

[3] $\mathrm{Li} \mathrm{Mu}$ zhou. Analysis the challenges of university teaching process brought by modern information technology [J]. Journal of Inner Mongolia Normal University (Education science edition). 2 011.24(7):1-5.

[4]Zhu Wei. Discussion on the teaching management mode of university based on network informatization models [J]. Educational Forum.2012.12:158-159.

[5] [U.S.] John S. Brubacher book. Wang Cheng-xu translated. Higher Education Philosophy [M].Zhejiang Education Press, 2002.101-102. 